\title{
SPRZĘŻENIE DYNAMICZNYCH ZDOLNOŚCI Z POTRZEBAMI KONSUMENCKIMI - WYCZUWANIE I ANTYCYPACJA
}

DOI: 10.33141/po.2020.03.04

\section{Maciej Mitręga}

\section{Wprowadzenie}

K oncepcja dynamicznych zdolności organizacji stała się jednym z najbardziej wpływowych nurtów myślowych w naukach o zarządzaniu w XXI wieku. W szczególności zaowocowało to pracami koncepcyjnymi i empirycznymi podejmowanymi $\mathrm{w}$ takich obszarach, jak: zarządzanie strategiczne, marketing strategiczny, zarządzanie łańcuchem dostaw czy zarządzanie produkcją. Skalę tego zjawiska można prześledzić, przeglądając wydania czasopisma Strategic Management Journal z ostatnich dwóch dekad (lata 1997-2017). W ramach tej niewielkiej liczby wydań specjalnych tego czasopisma aż dwa wydania poświęcone zostały tematyce właściwej dla dynamicznych zdolności, tj. ewolucji zdolności organizacji (Helfat, 2000, s. 10-11) oraz niestabilności źródeł przewagi konkurencyjnej (D’Aveni i in., 2010, s. 1371-1385).

Generalnie, w literaturze panuje opinia, że dynamiczne zdolności organizacji zapewniają monitorowanie tendencji konsumenckich i reorganizację zasobów przedsiębiorstwa w sposób zapewniający nadążanie za tymi zmianami, jednak rozważane są równie wielokierunkowe oddziaływania, gdzie organizacja nie tylko ma postawę reaktywną, ale
Przegląd Organizacji, Nr 3(962), 2020, s. 27-33

www.przegladorganizacji.pl ๑ Towarzystwo Naukowe Organizacji i Kierownictwa (TNOiK)

również proaktywną wobec tych zmian (Narver i in., 2004, s. 334-347). Celem niniejszego artykułu jest eksploracja przejawów stosowania dynamicznych zdolności w działaniach nakierowanych na klientów, a w szczególności identyfikacja współzależności pomiędzy dynamicznymi zdolnościami a tendencjami w potrzebach konsumenckich. Dla realizacji tego zamierzenia w pierwszej części artykułu zaprezentowano ramy koncepcji dynamicznych zdolności. Następnie scharakteryzowano zastosowane podejście w projekcie badań jakościowym oraz wybrane wyniki tych badań odnoszące się do współzależności pomiędzy dynamicznymi zdolnościami a tendencjami $\mathrm{w}$ potrzebach konsumenckich. $\mathrm{W}$ podsumowaniu sformułowano główne wnioski płynące z badań.

\section{W poszukiwaniu ram koncepcyjnych dynamicznych zdolności}

$\mathrm{K}$

orzenie koncepcji dynamicznych zdolności sięgają przede wszystkim do tzw. ewolucyjnej koncepcji strategii, która wprowadziła pojęcie „rutyny organizacji” 
i podobnie jako szkoła dynamicznych zdolności koncentrowała się na fenomenie zmiany organizacyjnej, ale zmianę tę traktowała bardziej jako efekt złożonych sprzężeń wewnątrzorganizacyjnych i na styku pomiędzy organizacją i jej otoczeniem niż jako bezpośredni efekt decyzji menedżerskich (Nelson, Winter, 1982). W poszukiwaniu ram koncepcji dynamicznych zdolności (DZ) należy na początku przyjąć, że nie ma właściwie jednej uzgodnionej definicji tego konstruktu. W znacznej mierze wynika to właśnie $\mathrm{z}$ tego, że koncepcja dynamicznych zdolności nakreślona oryginalnie przede wszystkim w dwóch pracach; D.J. Teece $i$ in. (1997, s. 509-533) oraz K.M. Eisenhardt i J.A. Martina (2000, s. 1105-1121) stała się motorem napędowym dla wielokierunkowych badań podejmowanych $\mathrm{w}$ bardzo wielu obszarach zarządzania, a nawet w ekonomii.

Pojęcie DZ, podobnie jak i cała koncepcja DZ, wzbudziło liczne kontrowersje (Barreto, 2010, s. 256-280; Newbert, 2007, s. 121-146) odnoszące się m.in. do abstrakcyjności stosowanych pojęć czy też tautologicznego charakteru formułowanych twierdzeń teoretycznych, np. w odniesieniu do „zdolności zmieniających zdolności”. Podobne kontrowersje i dylematy nie są jednak niczym wyjątkowym w procesie rozwoju struktury teoretycznej, a właściwie wydają się koniecznym etapem na drodze stopniowego dojrzewania paradygmatu. Zresztą w rozumieniu T.S. Kuhna (1968), określony paradygmat nigdy nie wyjaśnia badanych zjawisk w sposób idealny, a jedynie „zabiega” o uznanie środowiska akademickiego, rywalizując $\mathrm{z}$ innymi atrakcyjnymi strukturami teoretycznymi. Można zgodzić się z D.A. Shepherdem i R. Suddaby (2017, s. 65), którzy, analizując proces tworzenia teorii w naukach o zarządzaniu, twierdzą, że: „Akt nazwania głównych konstruktów zaraz we wstępnych etapach tworzenia teorii jest kluczowym krokiem, ponieważ nawet jeśli narracja teoretyczna nie jest jeszcze całkiem jasna, a sam konstrukt jest nieostry, akt formalnego nazywania zjawiska jest niezbędny dla koncepcyjnego wyodrębnienia go z masowego 'szumu' codziennych doświadczeń oraz masowego 'szumu' dotychczasowych badań". W tym sensie należy podkreślić, że termin „dynamiczne zdolności” okazał się bardzo fortunnie wybrany, ponieważ termin ten wskazuje na pewne ważne i intuicyjnie dostrzegane zjawiska zachodzące zarówno w samych współczesnych organizacjach, jak i ich otoczeniu.

Definiowanie DZ może okazać się łatwiejsze, jeśli zestawimy ze sobą DZ i zdolności organizacji rozumiane bardziej ogólnie. Jest to oczywiście warunek konieczny dla odróżnienia szkoły dynamicznych zdolności od szkoły zasobowej (Barney, 1991, s. 99-120), która poświęciła sporo uwagi zdolnościom rozumianym jako kluczowy zasób niematerialny - strategiczny wyróżnik firmy w otoczeniu. D.J. Teece (2014, s. 328-352) uważa, że dynamiczne zdolności wprowadzają nową jakość $\mathrm{w}$ zarządzaniu strategicznym, ponieważ wyjaśniają to, w jaki sposób firmy budują i modyfikują swoje przewagi kompetencyjne. Na tym tle w pracach na temat DZ pojawia się rozróżnienie pomiędzy „bazowymi zdolnościami” (ordinary/zero order/ operational capabilities) oraz „dynamicznymi zdolnościami” (dynamic capabilities). Te pierwsze są traktowane jako bardzo ważne, ponieważ pozwalają firmie skutecznie funkcjonować na bieżąco. J.A. Martin (2011, s. 121) ujmuje to w ten sposób, że bazowe zdolności „tworzą bezwładność niezbędną do tego, aby organizacja była kompatybilna ze swoimi obecny$\mathrm{mi}$ technologiami, istniejącymi oczekiwaniami rynku oraz zachowaniami konkurentów. Z kolei DZ to, według J.A. Martina (2011, s. 121), procesy, które „umożliwiają zarówno częściowe modyfikacje w zasobach firmy, jak i tworzenie nowych strategicznych zasobów, które nie przypominają tego, jak wcześniej funkcjonowała firma”. W podobnym duchu S.G. Winter (2003) sugeruje, że bazowe zdolności charakteryzują się tym, że zapewniają sprawność organizacji w zakresie obsługi obecnych, dobrze znanych klientów bądź obecnych technologii, podczas gdy DZ są niezbędne dla zdobywania nowych rynków oraz wdrażania nowych technologii.

Chociaż w literaturze brak jednej, w pełni akceptowanej definicji dynamicznych zdolności, konkurujące ze sobą dwa główne nurty teoretyczne DZ (Teece i in., 1997, s. 509-533; Eisenhardt, Martin, 2000, s. 1105-1121) mogą być traktowane jako niesprzeczne, ponieważ przyjmują one wspólne ramy dla pojęcia dynamicznych zdolności. Wówczas dynamiczne zdolności reprezentują swoistą zdolność wyższego rzędy organizacji nakierowaną na dostosowanie zdolności i zasobów bazowych do zmieniających się wymagań środowiska biznesowego.

O ile można przyjąć, że występuje pewien konsens w literaturze odnośnie do tego, czym są dynamiczne zdolności, zwłaszcza w relacji do innych zasobów i zdolności organizacji, o tyle trudniej jest odnaleźć taki konsensus odnośnie do wielowymiarowości dynamicznych zdolności. Chociaż prace D.J. Teece (1997, s. 509-533; 2007, s. 1319-1350) wskazały na 3-elementową konstrukcję dynamicznych zdolności (wyczuwanie, przechwytywanie i transformacja), to w następnych pracach dodawano kolejne elementy składowe. Przykładowo, P.A. Pavlou i D.A. El Sawy (2011, s. 239-273) zaproponowali 4-składnikowy model pomiarowy dla dynamicznych zdolności, gdzie elementami składowymi były: wyczuwanie, uczenie się, integrowanie i koordynacja. Propozycje te są jednak ze sobą niesprzeczne, ponieważ opierają się na wspólnym założeniu, że dynamiczne zdolności odnoszą się zarówno do procesów nakierowanych na identyfikowanie atrakcyjnych zasobów w otoczeniu, jak i procesów wewnątrzorganizacyjnych, które umożliwiają systematyczne przechwytywanie tych zasobów w skoordynowany sposób.

Chociaż w literaturze $\mathrm{z}$ zakresu zarządzania strategicznego przedmiotem badań są nierzadko dynamiczne zdolności rozumiane jako holistyczne rutyny odnoszące się do wszystkich dziedzin funkcjonowania organizacji, w odróżnieniu od zdolności bazowych (Pavlou, El Sawy, 2011, s. 239-273; Wilhelm i in., 2015, s. 327-345), należy podkreślić, że dynamiczne zdolności są również konceptualizowane jako metarutyny zmieniające zasoby i zdolności $\mathrm{w}$ określonych strategicznych dziedzinach biznesu, np. zarządzania łańcuchami dostaw (Lee, Rha, 2016, s. 2-23; Chowdhury, Quaddus, 2017, s. 185-204) i zarządzania marketingiem (Barrales-Molina i in., 2014, s. 397-416; Mitręga, 2019, s. 193-203). Można zatem 
przyjąć, że określone organizacje poprzez swoją specjalizację strategiczną rozwijają dynamiczne zdolności tylko w wybranych obszarach, a w przypadku najbardziej skutecznych organizacji możliwe jest nawet współistnienie kilku dynamicznych zdolności w obrębie jednej struktury organizacyjnej.

O ile łatwiej o konsensus w środowisku akademickim odnośnie do tego, że DZ są potrzebne współczesnym organizacjom, aby skutecznie funkcjonować w tzw. otoczeniu turbulentym, a także czym dynamiczne zdolności są w stosunku do zdolności bazowych, o tyle dużo trudniej jest określić, czym się właściwie przejawiają DZ na poziomie konkretnych działań podejmowanych przez organizacje na rynku czy też konkretnych rozwiązań strukturalnych i proceduralnych stosowanych w tych organizacjach. Ponadto w koncepcji dynamicznych zdolności niejasne są współzależności pomiędzy organizacją względnie wyodrębnioną $\mathrm{z}$ otoczenia rynkowego a tym otoczeniem, w tym sensie, że nie jest jasne, czy tendencje w otoczeniu mogą być jedynie „wyczuwane” przez organizacje czy też może tendencje te mogą być również tworzone przez organizacje czy w $\mathrm{z}$ znacznym zakresie podsycane. W tym kontekście warto zwrócić uwagę na ewolucję konstruktu orientacji rynkowej, który ma kluczowe znaczenie dla badań naukowych w marketingu, a który przechodzi stopniową ewolucję $\mathrm{z}$ reaktywnej orientacji rynkowej, zakładającej bardziej jednokierunkowe oddziaływania organizacji i otoczenia rynkowego do orientacji proaktywnej, w której potrzeby konsumenckie nie tylko są wyczuwane, ale organizacja skutecznie tworzy tendencje w potrzebach konsumenckich, które traktowane są jako uśpione (Narver i in., 2004, s. 334-347). W tym kontekście wartościowe poznawczo jest podjęcie próby identyfikacji przejawów stosowania dynamicznych zdolności $\mathrm{w}$ działaniach polskich i zagranicznych organizacji ze szczególnym uwzględnieniem współzależności pomiędzy procesami organizacji a tendencjami w zachowaniach konsumenckich, co nastąpi w dalszej części artykułu w oparciu o wyniki badań jakościowych.

\section{Charakterystyka badań jakościowych}

A by dokonać eksploracji przejawów DZ, zrealizowano badania jakościowe wśród celowo dobranych przedsiębiorstw. Wykorzystano wówczas zarówno wtórne, jak i pierwotne źródła informacji. Wtórne źródła informacji odnosiły się do publikacji w czasopismach branżowych czy też informacji zamieszczonych na witrynach korporacyjnych i umożliwiły głównie identyfikację przejawów DZ w działalności przedsiębiorstw zagranicznych. Gromadzenie informacji pierwotnych umożliwiło z kolei poznanie przejawów DZ w działalności przedsiębiorstw funkcjonujących w Polsce (w większości rdzennie polskich bądź posiadających strategiczne oddziały w Polsce) i opierało się na wywiadach częściowo standaryzowanych prowadzonych $\mathrm{z}$ menedżerami tych przedsiębiorstw. W sumie przeprowadzono wywiady z przedstawicielami 20 firm, przy czym w niniejszym artykule skoncentrowano się tylko na opiniach menedżerów 7 firm, w związku z ograniczeniami objętości tekstu oraz przy koncentracji na główny cel badania, jakim była identyfikacja współzależności pomiędzy procesami organizacji a tendencjami w potrzebach konsumenckich ${ }^{1}$. W ramach celowego doboru starano się dobierać firmy innowacyjne pod względem oferty rynkowej, zwłaszcza takie, które aktywnie poszerzają swoją ofertę i zakres obsługiwanego rynku. W tabeli 1 przedstawiono podstawowe informacje na temat firm, które wzięły udział $\mathrm{w}$ prowadzonych wywiadach $\mathrm{z}$ menedżerami. W trakcie badań jakościowych zgromadzono materiał empiryczny, na który składają się transkrypcje

Tabela 1. Charakterystyka firm biorących udziat w badaniu

\begin{tabular}{|c|c|c|c|c|c|}
\hline $\begin{array}{l}\text { Kod firmy lub } \\
\text { nazwa firmy }\end{array}$ & Branża & $\begin{array}{c}\text { Wielkość } \\
\text { przedsiębiorstwa } \\
\text { - liczba pracowników }\end{array}$ & $\begin{array}{c}\text { Udział eksportu } \\
\text { w obrotach } \\
\text { przedsiębiorstwa w \% }\end{array}$ & $\begin{array}{c}\text { Rynek } \\
\text { (B2C/B2B) }\end{array}$ & $\begin{array}{l}\text { Stanowisko } \\
\text { respondenta ** }\end{array}$ \\
\hline $\mathrm{Z}$ & Elektrotechniczna & Małe & Brak danych & $\mathrm{B} 2 \mathrm{~B}$ & Menedżer \\
\hline $\mathrm{H}$ & Chemia budowlana & Mikro & Między 30 a 50 & $\mathrm{~B} 2 \mathrm{~B}$ & Menedżer \\
\hline$\Omega$ & $\begin{array}{l}\text { Telekomunikacyjne } \\
\text { systemy, usługi }\end{array}$ & Duże & $\begin{array}{c}\text { Korporacja } \\
\text { międzynarodowa }^{*}\end{array}$ & $\mathrm{~B} 2 \mathrm{~B}$ & Menedżer \\
\hline$\Lambda$ & $\begin{array}{l}\text { Spożywcze artykuły, } \\
\text { dodatki, przyprawy }\end{array}$ & Bardzo duże & Między 20 a 40 & $\mathrm{~B} 2 \mathrm{C}$ & Menedżer \\
\hline BETA & Elektronika & Bardzo duże & $\begin{array}{c}\text { Korporacja } \\
\text { międzynarodowa }\end{array}$ & $\mathrm{B} 2 \mathrm{C} / \mathrm{B} 2 \mathrm{~B}$ & Menedżer \\
\hline Politan & $\begin{array}{c}\text { Nietrwałe produkty } \\
\text { gospodarstwa domowego }\end{array}$ & Średnie & Niewielki & $\mathrm{B} 2 \mathrm{C}$ & Członek Zarządu \\
\hline $\mathrm{C}$ & Elektronika & Bardzo duże & $\begin{array}{c}\text { Korporacja } \\
\text { międzynarodowa* }\end{array}$ & $\mathrm{B} 2 \mathrm{C} / \mathrm{B} 2 \mathrm{~B}$ & Menedżer \\
\hline
\end{tabular}

* Badania były realizowane w polskim oddziale korporacji transnarodowej, która orientuje się na rynek globalny.

** Ze względu na oczekiwania respondentów w zakresie anonimizacji kategoria Menedżer odnosi się do menedżerów komórek funkcjonalnych, czyli do takich stanowisk, jak: dyrektor marketingu, dyrektor sprzedaży, dyrektor ds. rynków zagranicznych, brand manager, dyrektor regionalny.

Żródto: opracowanie własne 
20 przeprowadzonych rozmów z menedżerami oraz 115 dokumentów tekstowych i graficznych dotyczących badanych przedsiębiorstw zgromadzonych ze źródeł wtórnych (zewnętrznych i wewnętrznych). Aby usprawnić pracę $\mathrm{w}$ ramach takiego bogatego zbioru danych, posłużono się na etapie analizy specjalistycznym oprogramowaniem klasy CAQDAS (komputerowe wspomaganie analizy danych jakościowych), tj. Atlas.ti 8.0.

\section{Wyniki badań}

$\mathbf{P}$ rzeprowadzone badania wskazały, że badane firmy przyjmują aktywną postawę wobec zmian na ryn$\mathrm{ku}$, tzn. nie tylko rozpoznają tendencje rynkowe i się do nich dostosowują, ale również same prowadzą czasem do głębokich przeobrażeń w konsumenckich preferencjach. Ogólnie można zauważyć, że badane przedsiębiorstwa stosują szeroki wachlarz metod i technik badań marketingowych. Firmy chętnie sięgają do tzw. pierwotnych źródeł informacji. W tym względzie nie tylko posiłkują się współpracą z agencjami badawczymi, czy też wprowadzają jakieś specjalne instrumenty pomiarowe, ale przede wszystkim korzystają z wszystkich punktów styku pomiędzy ich personelem (zwłaszcza działem handlowym) a różnymi interesariuszami, które mogą być źródłem cennych informacji, np.:

- $w$ odniesieniu do sprzedaży artykułów chemii budowlanej: „najlepszym źródłem informacji jest klient” [Firma H],

- w odniesieniu do sprzedaży artykułów spożywczych: „(...) szybkość reakcji na te innowacje patrz: musimy coś zmienić, z tego działu bardziej operacyjnego handlowego, jest bardzo duży nacisk na to" [Firma $\Lambda$ ].

Duże znaczenie $\mathrm{w}$ badanych przedsiębiorstwach odgrywają procesy, które umożliwiają niestandaryzowane pozyskiwanie informacji. Co prawda, techniki takie narażone są mocno na błędy wynikające ze specyficznych cech samej osoby gromadzącej informacje, jak również dynamiki interakcji z respondentami, jednak umożliwiają one szybki i stosunkowo tani dostęp do bardzo aktualnych informacji, w tym takich, które dotyczą sytuacji na rynku międzynarodowym. W przypadku małych organizacji, które nie dysponują znaczącymi budżetami na cele marketingowe, umożliwia to systematyczne budowanie wiedzy o rynku. Ilustruje to wypowiedź menedżera z firmy Z, która oferuje układy elektryki i automatyki na rynku B2B: „O nowych rzeczach na rynku dowiadujemy sie, jeżdżac na konferencje, spotykając się z ludźmi, słuchając wykładów".

Część respondentów wyraźnie wskazała na to, że ich przedsiębiorstwa nie tylko wyczuwają zmiany w otoczeniu i dostosowują swoje kompetencje do tych zmian, ale odgrywają znacznie bardziej aktywną rolę w tych zmianach. Wobec takiego podejścia do rynku stosowne wydaje się użycie pojęcia „antycypacja zmian”, ponieważ pojęcie to odnosi się zarówno do aspektów bardziej pasywnych (budowanie wiedzy o otoczeniu), jak i bardziej aktywnych (stymulowanie zmian w otoczeniu). Ilustruje to fragment wypowiedzi menedżera $\mathrm{z}$ międzynarodowego koncernu $\mathrm{C}^{2}$ : „Wyprzedzają myślenie, co klient potrzebuje. Szybciej jest to wdrażane, niż tak naprawde klient wie, że taka potrzebę będzie miat".

Wydaje się, że szczególne znaczenie $\mathrm{w}$ procesie antycypacji odgrywają działania komunikacyjne oparte na mechanizmie społecznego dowodu słuszności (Cialdini, 2004, s. 186-195). Mechanizm ten wyraża się w tym, że badane przedsiębiorstwa starają się poprzez media masowe promować określone potrzeby niedostrzegane dotychczas w sferze publicznej, bądź same produkty zaspokajające te potrzeby, jako trend właśnie. Takie komunikaty prezentują określone zjawisko jako akceptowane przez szerokie kręgi społeczne bądź przynajmniej budzące powszechne zaciekawienie z uwagi na jakieś wyjątkowe cechy itp. Konsument zaczyna identyfikować się z takim nagłaśnianym "trendem”, bo chce być podobny do innych, akceptowany itd. W przeprowadzonych wywiadach dostrzeżono dwa swoiste warianty odnoszące się do zdolności organizacji:

1. Potrzeba rzeczywiście wyłania się jako oddolny proces, a zdolności organizacji nakierowane są na wykorzystanie okazji - w takich sytuacjach organizacja dostrzega, że pewien niedosyt w zakresie potrzeb konsumenckich istnieje ale nie jest przedmiotem publicznej debaty, więc przedsiębiorstwo uruchamia swoje zdolności, aby potrzebę najpierw rozpoznać, a następnie nagłośnić wraz z rynkową ofertą dopasowaną do określonego niedosytu. W takiej sytuacji często wykorzystywanym narzędziem jest przeprowadzenie badań opinii, które stanowią społeczny dowód powszechności określonego zjawiska. Takie działania podejmował międzynarodowy koncern $\Omega$, który dostarcza zaawansowane systemy telekomunikacyjne nabywcom instytucjonalnym: „Robimy projekt badawczy po to, żeby efekty tych badań można byto przedstawić instytucjom publicznym. Chodzi o to, aby skłonić rządzacych do zmiany prawa, która to zmiana jest $w$ interesie publicznym. Kreowanie biznesu i szukanie biznesu to jest proces poszukiwania szans rynkowych, a czasami kreowania przyjaznych uwarunkowań społeczno-ekonomicznych dla zaoferowania posiadanych w portfolio produktów" (...). Proszę sobie wyobrazić, że dwa lata wcześniej niż wprowadzono system trwały prace przygotowywane przez Uniwersytet $w$ mieście (...). Została opracowana cała komunikacja społeczna, do tego stopnia, że nawet mieszkańcy decydowali o wysokości stawek za parkowanie w mieście. Ba, wprowadzono ten system na pół roku jako test, po czym władze miasta zapytały mieszkańców - to co, chcecie, żeby testowany system funkcjonowat w mieście czy też kończymy i zarzucamy projekt? Okazało się, że mieszkańcy w 90\% poparli pomysł władz miasta, mówili - tak, jest teraz fajniej!”.

2. Potrzeba nie jest odczuwana, ale jest kreowana poprzez zdolności organizacji - z taką sytuację mamy do czynienia w przypadku klientów indywidualnych, którzy w poszukiwaniu inspiracji zakupowych kierują się informacjami rozpowszechnianymi w mediach, zwłaszcza w formie różnych testów czy recenzji. Chociaż tzw. moralny cykl życia niektórych typów produktów jest współcześnie krótki (np. sprzętu RTV), 
jednak klienci nie zawsze zainteresowani są nowymi funkcjonalnościami związanymi z produktami, ponieważ dotychczas używane produkty są jeszcze w pełni sprawne i masowo używane przez osoby z tej samej społecznej grupy odniesienia. Dopiero wykorzystanie zasady społecznego dowodu słuszności poprzez organizacje dysponujące odpowiednimi marketingowymi zdolnościami zwraca uwagę na innowacje. Ilustruje to wypowiedź menedżera firmy Beta - producenta sprzętu RTV: „Ważne jest to co mówiłem, ze my staramy się dla tych głównych innowacji tworzyć taka sytuacje, że w momencie kiedy produkt zaczyna być sprzedawany to już jakby w tych touchpointach jest content na ten temat. Właśnie rates and reviews, jakieś artykuły związane z tymi produktami, czy $z$ ta kategoria, jakieś wideo, czy jak tego używać. I to powoduje, że jak ten produkt zaistnieje i sie pojawi, to nie ma takiej sytuacji, że wiesz, nie wiadomo co to jest. To ułatwia ta ścieżkę zakupowa czy decyzyjna".

Wywiady dostarczyły też przesłanek przemawiających za tezą, że nawet firmy średnie i małe mogą skutecznie uprzedzać rynkowe tendencje poprzez opracowywanie i wprowadzenie do obrotu produktów o wyjątkowej jakości technicznej czy przełomowej funkcjonalności. Produkty takie mogą później wyznaczać standard dla innych organizacji z branży. Ilustruje to wypowiedź menedżera firmy Politan ${ }^{3}$, „Z pewnościa moge powiedzieć, że wykreowaliśmy jeden trend i stworzyliśmy kategorię produktów. Ten produkt jest liderem w swoim rynku. Osobiście, to czy produkt wytworzył trend czy też nie, mierze w ilości podróbek. I faktycznie jest ich dość sporo. W tym zakresie, jeden taki produkt na pewno stworzyliśmy". O zdolnościach małych firm w zakresie antycypacji rynku świadczą również działania opisane przez menedżera firmy Z, które wymagaja przyjęcia długookresowego podejścia do podejmowanych inwestycji: „My po pierwsze wchodzimy w jednq taka technologię, że jesteśmy jedna $z$ kilku firm $w$ Europie $i$ jedyna $w$ Polsce, która ta technologię posiada. To jest bardziej na razie technologia, która nam daje prestiz, a rynek to tak jeszcze nie do końca jest wykreowany na ta technologie, ale jest to właśnie technologia pomiaru synchronicznego. Dostaliśmy $w$ tamtym roku nagrodę XYZ, właśnie za tą technologię".

\section{Podsumowanie}

W niniejszym artykule scharakteryzowano ramy dynamicznych zdolności, które mieszczą się w tzw. mainstreamie omawianego nurtu badawczego, a jednocześnie byłyby zgodne z różnorodnością prac podejmowanych na temat dynamicznych zdolności przez badaczy poszczególnych obszarów zarządzania organizacją. Mając na uwadze, że jednym z głównych, jeśli nie najważniejszym ograniczeniem koncepcji dynamicznych zdolności jest jej abstrakcyjny charakter, w niniejszym artykule zaprezentowano wybrane wyniki badań własnych nakierowanych na eksplorację dynamicznych zdolności w praktyce funkcjonowania polskich i zagranicznych przedsiębiorstw. Były to przedsiębiorstwa dobierane celowo, w związku z czym zaprezentowane wyniki badań nie reprezentują bynajmniej jakiś ogólnych tendencji $\mathrm{w}$ populacji przedsiębiorstw w Polsce, np. pod względem dominującego sposobu badania rynku, dynamiki innowacji produktowych bądź organizacyjnych. Badania były realizowane $\mathrm{w}$ interpretatywnym podejściu badawczym (Sułkowski, 2006, s. 135-143), w związku z czym podlegały ograniczeniom związanym ze specyficznymi doświadczeniami i kognicją badacza. Tym niemniej egzemplifikacje i propozycje teoretyczne są potrzebne na obecnym etapie rozwoju wyłaniającego się paradygmatu, ponieważ ułatwiają one operacjonalizacje skomplikowanych konstruktów teoretycznych i realizacje potencjalnych badań konfirmacyjnych, w tym tych opartych na dużych próbach badawczych.

Przeprowadzone badania jakościowe dostarczają przesłanek przemawiających za tezą o wielokierunkowości oddziaływań pomiędzy organizacją a tendencjami konsumenckimi w przypadku stosowania dynamicznych zdolności. Teza ta koresponduje $\mathrm{z}$ innym nurtem badawczym w literaturze z zakresu marketingu, ponieważ zaproponowana została już w pracy J.C. Narvera i innych (2004, s. 334-347) w związku z tzw. rekonceptualizacją orientacji rynkowej współczesnych przedsiębiorstw i antycypowaniem ukrytych czy też uśpionych potrzeb konsumenckich w miejscu bardziej reaktywnych działań wobec zauważanych tendencji, czyli tradycyjnej orientacji rynkowej. Tym niemniej warto podkreślić, że koncepcja tzw. proaktywnej orientacji rynkowej nie wyparła koncepcji orientacji rynkowej ani nawet nie spotkała się z szerokim oddźwiękiem $\mathrm{w}$ pracach badaczy specjalizujących się $\mathrm{w}$ marketingu. Można się o tym przekonać, porównując liczbę prac naukowych indeksowanych w Google Scholar, które od 2004 roku koncentrowały się na obu tych koncepcjach. W przypadku proaktywnej orientacji rynkowej jest to tylko 63 publikacji naukowych, a w przypadku orientacji rynkowej to aż 5470 publikacji naukowych ${ }^{4}$. Współoddziaływanie organizacji i otoczenia rynkowego jest w ogóle rzadko podejmowanym wątkiem przez badaczy zarządzania, w tym również badaczy dynamicznych zdolności, ponieważ z reguły widać w pracach założenie implicite, że organizacja jedynie dostosowuje się do zmian w otoczeniu, zwłaszcza w odniesieniu do „wyczuwania” (sensing) jako fundamentu dynamicznych zdolności. Wyniki badań jakościowych, których fragmenty przedstawiono w niniejszym artykule ${ }^{5}$ sugerują, że oprócz „wyczuwania” adekwatnym terminem wobec procesów biznesowych nakierowanych na tendencje rynkowe jest „antycypacja”, ponieważ termin ten podkreśla dwukierunkowość oddziaływań pomiędzy organizacją a otoczeniem. Przykłady działań polskich i zagranicznych organizacji wyraźnie pokazują, że współczesne organizacje stosują różne narzędzia, aby nie tylko rozpoznawać, ale także umiejętnie podsycać czy też całkowicie kreować potrzeby konsumenckie.

Można przyjąć, że potencjał wykorzystania dynamicznych zdolności wobec zachowań konsumenckich jest większy w przypadku firm zasobnych, które mogą wykorzystywać korzyści skali i prowadzić duże inwestycje technologiczne na skalę globalną. Tym niemniej mniejsze firmy też mogą starać się oddziaływać na tendencje konsumenckie na rynkach regionalnych, zwłaszcza z wyko- 
rzystaniem mediów społecznościowych, biorąc pod uwagę jednostkowo niższe koszty działań w tym kanale. W tym kontekście warto też zastanowić się, czy opisywanie tzw. nowych mediów jako czynnika sprzyjającego tzw. uprawomocnieniu konsumentów i zmniejszeniu asymetrii informacji w relacjach na styku organizacje-konsumenci wyczerpuje to, co obecnie obserwujemy w praktyce biznesowej. Na tym tle szczególnie dotkliwie rysuje się rozdźwięk między niektórymi współczesnymi koncepcjami w naukach o zarządzaniu a wynikami obserwacji rynkowych. Przykładem może być tutaj koncepcja tzw. logiki usługowej marketingu, która przenosi zainteresowanie badaczy na takie działania podmiotów rynkowych (przedsiębiorstw, konsumentów), które prowadzą do obopólnego wzrostu dobrostanu, czyli tzw. wellbeing. Oczywiście podobne działania mogą pojawiać się w rzeczywistości gospodarczej, jednak trudno nie zgodzić się z R.S. Achrol i P. Kotlerem (2012, s. 35-52), że nie jest to jeszcze dominująca tendencja, a popularyzacja podobnych działań wymaga głębokich przemian w sposobach myślenia i działania.

\section{prof. dr hab. Maciej Mitręga \\ Uniwersytet Ekonomiczny w Katowicach Kolegium Informatyki i Komunikacji \\ ORCID: 0000-0003-4043-5589 \\ e-mail: maciej.mitrega@ue.katowice.pl \\ Przypisy}

1) Zobacz szerzej wyniki badań na temat dynamicznych zdolności marketingowych: Mitręga, 2018, s. 99-149.

2) W przypadku większości badanych firm nie uzyskano zgody na ujawnienie nazwy firmy ani nazwiska/stanowiska respondenta, w związku $\mathrm{z}$ tym informacje te zostały poddane anonimizacji.

3) W przypadku nielicznych spośród badanych przedsiębiorstw uzyskano zgodę na ujawnianie ich nazwy.

4) Dane zebrane $w$ dniu 09.05.2020 r. poprzez porównanie liczby publikacji stosujących określone słowo kluczowe w tytule.

5) Więcej informacji na temat dynamicznych zdolności marketingowych: Mitręga, 2018, s. 99-149.

\section{Bibliografia}

[1] Achrol R.S., Kotler P. (2012), Frontiers of the Marketing Paradigm in the Third Millennium, ,Journal of the Academy of Marketing Science", Vol. 20, No. 1, pp. 35-52.

[2] Barney J.B. (1991), Firm Resources and Sustained Competitive Advantage, „Journal of Management”, Vol. 14, No. 1, pp. 99-120.

[3] Barrales-Molina V., Martínez-López F. J., Gázquez-Abad J.C. (2014), Dynamic Marketing Capabilities: Toward an Integrative Framework, „International Journal of Management Reviews", Vol. 15, No. 4, pp. 397-416.

[4] Barreto I. (2010), Dynamic Capabilities: A Review of Past Research and an Agenda for the Future, „Journal of Management", Vol. 36, No. 1, pp. 256-280.

[5] Cialdini R. (2004), Wywieranie wpływu na ludzi. Teoria i praktyka, GWP, Warszawa.
[6] Chowdhury M.M., Quaddus M. (2017), Supply Chain Resilience: Conceptualization and Scale Development Using Dynamic Capability Theory, „International Journal of Production Economics", Vol. 188, pp. 185-204.

[7] D'Aveni R.A, Dagnino G.B., Smith K.G. (2010), Special Issue: The Age of Temporary Advantage? „Strategic Management Journal", Vol. 31, No. 13, pp. 1371-1385.

[8] Eisenhardt K.M., Martin J.A. (2000), Dynamic Capabilities: What Are They? „Strategic Management Journal”, Vol. 21, No. 10-11, pp. 1105-1121.

[9] Helfat C.E. (2000), Special Issue: The Evolution of Firm Capabilities, „Strategic Management Journal”, Vol. 21, pp. $10-11$.

[10] Kuhn T.S. (1968), Struktura rewolucji naukowych (tłum.) PWN, Warszawa.

[11] Lee S.M., Rha J.S. (2016), Ambidextrous Supply Chain as a Dynamic Capability: Building a Resilient Supply Chain, „Management Decision”, Vol. 54, No. 1, pp. 2-23.

[12] Martin J.A. (2011), Dynamic Managerial Capabilities and the Multibusiness Team: The Role of Episodic Teams in Executive Leadership Groups, „Organization Science”, Vol. 22, No. 1, pp. 118-140.

[13] Mitręga M. (2019), Dynamic Marketing Capability-refining the Concept and Applying it to Company Innovations, „Journal of Business \& Industrial Marketing", Vol. 35, No. 2, pp. 193-203.

[14] Mitręga M. (2018), Dynamiczne zdolności marketingowe organizacji. Koncepcja i wybrane obszary zastosowań, Wydawnictwo Uniwersytetu Ekonomicznego w Katowicach, Katowice.

[15] Narver J.C., Slater S.F., MacLachlan D.L. (2004), Responsive and Proactive Market Orientation and New-product Success, „Journal of Product Innovation Management”, Vol. 21, No. 5, pp. 334-347.

[16] Nelson R.R., Winter S.G. (1982), An Evolutionary Theory of Economic Change, Harvard University Press.

[17] Newbert S.L. (2007), Empirical Research on the Resource-based View of the Firm: An Aseessment and Suggestions for Future Research, „Strategic Management Journal”, Vol. 28, No., pp. 121-146.

[18] Pavlou P.A., El Sawy O.A. (2011), Understanding the Elusive Black Box of Dynamic Capabilities, „Decision Sciences”, Vol. 42, No. 1, pp. 239-273.

[19] Shepherd D.A., Suddaby R. (2017), Theory Building: A Review and Integration, „Journal of Management”, Vol. 43, No. 1 , pp. 59-86.

[20] Sułkowski Ł. (2006), Perspektywa interpretatywna $w$ naukach o zarzadzaniu, Prace Naukowe Akademii Ekonomicznej we Wrocławiu, Nr 1104, s. 135-143.

[21] Teece D.J., Pisano G., Shuen A. (1997), Dynamic Capabilities and Strategic Management, „Strategic Management Journal", Vol. 18, No. 7, pp. 509-533.

[22] Teece D.J. (2007), Explicating Dynamic Capabilities: The Nature and Microfoundations of (Susainable) Enterprise Performance, „Strategic Management Journal”, Vol. 28, pp. 1319-1350.

[23] Teece D.J. (2014), The Foundations of Enterprise Performance: Dynamic and Ordinary Capabilities in an (Economic) Theory of Firms, „The Academy of Management Perspectives", Vol. 28, No. 4, pp. 328-352. 
[24] Wilhelm H., Schlömer M., Maurer I. (2015), How Dynamic Capabilities Affect the Effectiveness and Efficiency of Operating Routines Under High and Low Levels of Environmental Dynamism, „British Journal of Management”, Vol. 26, No. 2, pp. 327-345.

[25] Winter S.G. (2003), Understanding Dynamic Capabilities, „Strategic Management Journal”, Vol. 24, No. 10, pp. 991-995.

\section{The Link between Dynamic Capabilities and Consumer Tendencies - Sensing and Anticipation}

\section{Summary}

The dynamic capabilities concept (DC) is one of the most influential intellectual streams in management science in this century, but this concept is still somehow abstract with regard to business practice. This paper proposes boundaries of dynamic capabilities that are positioned within theoretical origins on this very concept and, at the same time, combines some distinct streams in DC literature. This paper presents selected results of qualitative research oriented at exploring DC in business practice with special emphasis on interlink between dynamic capabilities and emerging tendencies in consumer needs. The research results suggest that this interlink is two-directional as contemporary companies use various tools to leverage consumer tendencies. Thus, „anticipation” could be a complementary term in relation to "sensing” as building block of dynamic capabilities.

\section{Keywords}

dynamic capabilities, paradigm, strategic management, marketing, consumer tendencies 